\title{
KAJIAN PENERAPAN PENDAMPINGAN PENELITIAN TINDAKAN KELAS KOLABORATIF ANTARA PERGURUAN TINGGI DAN SEKOLAH
}

\author{
Zulfiani, Yanti Herlanti, Ahmad Sofyan \\ Univeritas Islam Negeri Syarif Hidayatullah \\ email: zulfiani@uinjkt.ac.id
}

\begin{abstract}
Abstrak: Penelitian bertujuan menemukan model pendampingan penelitian tindakan kelas kolaboratif antara perguruan tinggi dan sekolah (PTK Kolaboratif). Penelitian dilakukan di sekolah mitra. Metode penelitian menggunakan Mixed Method. Instrumen pengumpulan data adalah kuesioner, lembar wawancara mendalam, catatan lapangan, dan FGD. Data dianalisis dengan teknik statistik deskriptif. Penelitian menghasilkan tiga model Pendampingan PTK Kolaborasi yaitu model I (guru bersifat dominan), model II (peran guru bersifat moderat), dan model III (guru bersifat resesif). Model I guru sebagai pencetus ide dan melakukan penelitian mandiri, mahasiswa berperan sebagai observer, proses bimbingan dilakukan oleh dosen pembimbing. Model II guru dan mahasiswa mencetuskan ide riset, guru melaksanakan PTK, proses bimbingan dilakukan oleh dosen pembimbing. Model III guru bersama mahasiswa atau mahasiswa secara mandiri mencetuskan ide riset, mahasiswa melaksanakan PTK, proses bimbingan dilakukan dosen. Respon dosen, mahasiswa dan guru, positif terhadap pelaksanaan semua model kolaborasi PTK. Validasi pakar menunjukkan Model II dianggap sebagai model pendampingan kolaboratif perguruan tinggi dan sekolah yang ideal.
\end{abstract}

\section{Keyword: model pendampingan kolaboratif, penelitian tindakan kelas}

\section{A STUDY ON THE IMPLEMENTATION OF UNIVERSITY - SCHOOL COLLABORATIVE CLASSROOM ACTION RESEARCH (CAR)}

\begin{abstract}
The goal of the study is to find out the mentoring models in collaborative Classroom Action Research (CAR) involving university and school. Research was carried out at the partner school. Deployingmixed methods, data were collected through questionnaire, depth interview, field note and FGDs and then analyzed using descriptive statistics technique. The results show three mentoring models in collaborativeCAR i.e. Model I (dominant teacher-oriented), Model II (moderateteacher-oriented), and Model III (recessive teacher-oriented). Model I requires teacher to undertake the CAR, studentto act as the observer, and lecturer to act as the mentor.In Model II, student and teacher propose a research problem, teacher conducts the CAR, and lecturermentors them. In Model III, teacher and student(or only student) formulate the research problem, student undertakes the CAR, and lecturer mentors them. Lecturers, students and teachers positively responds to the implementation of all the models. However, expertsargue that Model II is the ideal model for collaboration between university and school.
\end{abstract}

\section{Keyword: collaborative mentoring model, classroom action reserach}

\section{PENDAHULUAN}

Sesuai pasal 1 ayat 1 Undang-Undang Repubik Indonesia No. 14/2005, guru adalah pendidik profesional memiliki tugas utama mendidik, mengajar, membimbing, mengarahkan, melatih, menilai, dan mengevaluasi peserta didik pada jalur pendidikan formal, pendidikan dasar, dan pendidikan menengah (Indonesia, 2005:6). Tugas utama tersebut melekat pada diri pendidik secara holistik yang terimplementasi pada proses pembelajaran di kelas. Sejumlah tugas utama tersebut merupakan bentuk optimalisasi kompetensi yang harus dimiliki seorang pendidik.

National Research Council (1996:67) menegaskan profesionalisme guru sains perlu mengintegrasikan pengetahuan sains, pembelajaran dengan perspektif strategi pengajaran terbaru dan berbasis inkuiri. Setidaknya terdapat 5 hal yang perlu dituntut seorang guru profesional : (1) guru memiliki komitmen pada siswa dan proses belajarnya, (2) guru menguasai secara mendalam terkait konten bahan ajarnya serta cara mengajar- 
kannya, (3) bertanggungjawab memantau hasil belajar siswa melalui berbagai cara evaluasi, (4) guru mampu berpikir sistematis tentang apa yang dilakukaknya dan belajar dari pengalamannya, (5) guru merupakan bagian dari masyarakat belajar dalam lingkungan profesinya. Selain itu kemampuan melakukan penelitian tindakan kelas menjadi salah satu kemampuan yang diperlukan guru yang dapat menjadikan guru sebagai pengajar sekaligus 'pembelajar' aktif.

Kreativitas guru bukan hanya dalam hal penerapan IPTEK, tetapi juga pengembangan metode-metode pembelajaran yang sederhana tetapi sesuai dengan karakter bangsa dan pengembangan materi ajar untuk memperkaya ilmu pengetahuan. Metode pembelajaran tidak harus menggunakan peralatan yang canggih, tetapi yang penting peserta didik termotivasi untuk belajar lebih baik. Nurjhani, et al (2008:1) menyatakan guru masih kesulitan mengembangkan metode, pendekatan dan media pembelajaran yang up date sesuai dengan kondisi siswa dan perkembangan masyarakat.

Produk inovasi yang kontekstual tentu saja lahir dari kajian mandiri guru melalui serangkaian penelitian yang sistematis, salah satunya melalui melalui Penelitian yang dilakukan melalui aktivitas peneltian tindakan kelas (PTK). Aturan baru Angka Kredit bagi kenaikan Jabatan Guru ini, sudah berlaku efektif mulai tanggal 1 Januari 2013, dimana untuk kenaikan pangkat jabatan Fungsional Guru serendah-rendahnya Golongan III/b diwajibkan membuat Karya Inovatif berupa Penelitian, Karya Tulis Ilmiah, Alat Peraga, Modul, Buku, atau Karya Teknologi Pendidikan yang nilai angka kreditnya disesuaikan (Mendiknas dan BKN, 2010:22)

Usaha peningkatan profesionalitas guru dalam komunitasnya seringkali mengalami hambatan, terlebih lagi ketika banyak pelaku pendidikan (misalnya, pemangku kebijakan, kepala sekolah, guru, siswa, orang tua, institusi pendidikan, peneliti, donatur) yang terlibat di dalamnya, misalnya pada kegiatan aksi kolaborasi perguruan tinggi dan sekolah. Hal ini dikarenakan masingmasing kelompok pelaku pendidikan memiliki persepsi dan tujuan yang berbeda dalam memandang usaha profesionalitas guru yang sedang dilakukan. Hambatan yang ditimbulkan seringkali menyebabkan tujuan dari usaha peningkatan profesionalitas guru justru tidak tercapai atau bahkan terhenti (Akkerman \& Bakker, 2013:133).
Dalam usaha menjembatani pelaku pendidikan tersebut, penting memperhatikan bentuk kolaborasi pendampingan yang efektif antara perguruan tinggi dan sekolah. Bentuk kolaborasi pendampingan diusulkan sebagai upaya keterlibatan penuh dan konsisten antara kedua belah pihak.

Bentuk pendampingan sudah banyak dilakukan misalnya melalui Lesson study yang telah berkembang sejak tahun 1990 di Jepang, dan menjadi sangat familiar di Indonesia melalui IMSTEP tahun 1998 di tiga IKIP (sekarang UPI, UNY, dan UM) (Hendayana, dkk., 2004). Kegiatan profesionalitas guru umumnya berjalan dengan pola: diinisiasi dari pihak luar (peneliti, pemangku kebijakan, badan pelatihan, perguruan tinggi) guru diberikan pelatihan atau workshop kemudian mengaplikasikan hasil pelatihan di kelas dengan harapan mampu meningkatkan hasil belajar siswa. Kegiatan semacam ini seringkali tidak memberikan hasil yang memuaskan, misalnya, guru tidak mengalami perubahan terutama secara profesional, ilmu diperkenalkan melalui pelatihan atau workshop seringkali tidak dapat diaplikasikan di kelas, hasil belajar siswa tidak juga meningkat, dan terlebih lagi kegiatan pelatihan guru tidak berlangsung lama. Umumnya pemberdayaan guru/calon guru terkait PTK dilakukan saat guru mendapatkan pelatihan khusus (Rosiani, et. al., 2013:69)

Alasan lainnya adalah adalah bahwa hasil dari pelatihan tidak memberikan dampak perubahan positif kepada siswa, seperti motivasi belajar dan hasil belajar siswa. Padahal perubahan positif ini merupakan tujuan utama kegiatan profesionalitas guru perubahan yang terjadi pada siswa, dalam beberapa studi, ternyata telah mempengaruhi perilaku guru dan pelaku pendidikan lain (Agung, et.al , 2012:4). Dari contoh di atas, dapat dilihat bahwa pihak luar (Perguruan Tinggi) memiliki potensi yang sangat besar untuk memberikan pengaruh terhadap upaya-upaya peningkatan pendidikan. Dalam kaitannya dengan komunitas guru, misalnya, dapat dikatakan bahwa sekolah-perguruan tinggi memiliki peluang sinergis yang kiranya dapat menjembatani para pelaku pendidikan untuk memberikan dukungan terhadap upaya peningkatan profesionalitas guru melalui pendampingan. Bentuk kolaborasi dipengaruhi beberapa faktor tujuan, komunikasi, faktor organisasi, kurikulum (Tytler, et al 2016:14 ). 
Pada penelitian ini rancangan kolaborasi mengacu pada Program Profesi Keguruan Terpadu (PPKT) di Fakultas Ilmu Tarbiyah dan Keguruan (FITK) UIN Jakarta yang telah memiliki mitra 100 sekolah. Program ini memberikan kesempatan kepada mahasiswa untuk mengembangkan kompetensi guru yang harus mereka miliki secara terlatih seperti keterampilan mahasiswa mengajar, keterampilan meneliti dasar, dan pengembangan kepribadian dan sosial melalui pengabdian administrasi dan kependidikan. Kegiatan ini dilaksanakan selama 4 bulan di sekolah dengan jumlah mahasiswa 1-2 orang per sekolah. Setiap sekolah dibimbing oleh 1 orang dosen pembimbing PPKT dari Prodi/Jurusan yang berkesesuian dengan mahasiswa yang ditempatkan (FITK, UIN Jakarta, 2015:5).

Bentuk kolaborasi sebelumnya seringkali berakhir dengan selesainya program dan kerjasama ini akan dimulai kembali di tahun berikutnya. Masukan, saran dari pihak sekolah melalui proses Monitoring dan Evaluasi (Monev) Fakultas, ataupun personal langsung dari pihak sekolah kepada dosen dikomunikasikan kepada pihak Jurusan/ Prodi untuk menindaklanjuti Program kerjasama lain. Pihak sekolah mengharapkan perguruan tinggi memberikan bimbingan tidak hanya pada penguasaan konten materi Biologi, metodologi pembelajaran, namun pada kemampuan melakukan penelitian khususnya Penelitian Tindakan Kelas (PTK). Maka, hasil MONEV pelaksanaan kegiatan ini merekomendasikan bentuk kerjasama Perguruan Tinggi dan Sekolah yang bersifat mutualisme . Komponen model kolaborasi beranjak di perguruan tinggi-sekolah yang melibatkan dosen, guru, dan mahasiswa calon guru Prodi Pendidikan Biologi. Dalam pelaksanaannya model kolaborasi pendampingan guru bersinergi dengan aktivitas mahasiswa calon guru di sekolah mitra Perguruan Tinggi.

Kolaborasi perguruan tinggi-sekolah berpotensi besar untuk meningkatkan kualitas hasil belajar peserta didik melaui peningkatan profesionalisme guru. Maka, diperlukan penelitian yang dapat menemukan sebuah model pendampingan PTK yang mampu meningkatkan keterampilan meneliti para guru, sekaligus memberikan kesempatan kepada calon guru memperoleh contoh langsung praktik penyelesaian masalah di kelas. Sejauh ini belum ada penelitian yang memberikan penekanan terhadap kolaborasi secara berimbang antara calon guru, guru, dan dosen.

Penelitian ini memiliki signifikansi sebagai pintu pembuka yang diharapkan mampu mengeksplorasi lebih lanjut peran perguruan tinggi LPTK dalam upaya peningkatan profesionalitas guru dan keberlangsungan kenaikan pangkat guru yang berkualitas dan pemberian pengalaman calon guru menyelesaikan masalah pembelajaran di kelas. Maka, artikel ini akan mendeskripsikan hasil temuan model pendampingan PTK kolaboratif perguruan tinggi-sekolah.

\section{METODE}

Penelitian dilakukan dengan menggunakan model penelitian kombinasi (mixed method) concurent embeded (Sugiyono, 2012:538). Model penelitian yang digunakan ditunjukkan pada Gambar 1.

Pengumpulan data secara kuantitatif dilakukan dengan cara penyebaran angket kepada seluruh guru IPA dan guru Biologi di SMP/MTs dan SMA/MA di 41 sekolah mitra di Tangerang Selatan, Bogor, Depok dan Jakarta Selatan, dan
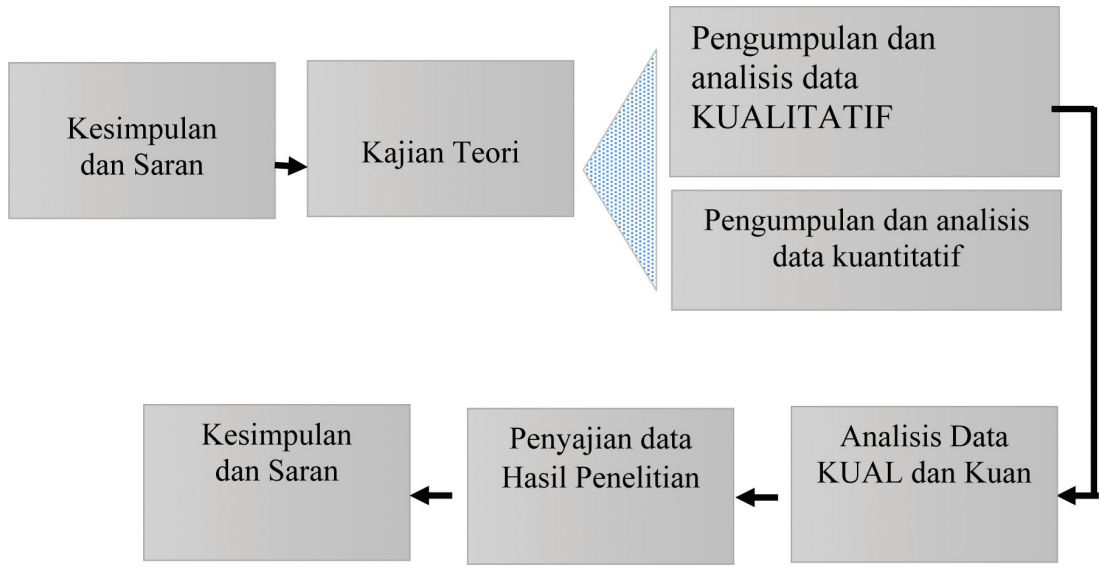

Gambar 1. Metode Penelitian Kombinasi Concurent Embeded, Metode Kualitatif sebagai Metode Primer 
angket yang dikembalikan berjumlah 26 responden dari 19 sekolah mitra. Hasil angket ini dianalisis secara statistik deskriptif. Data hasil angket digunakan sebagai kajian awal melihat kesulitan para guru dalam melakukan penelitian tindakan kelas. Data digunakan untuk memberikan tindakan dalam mengatasi kesulitan tersebut-

Pengumpulan data kualitatif dilakukan melalui Forum Discussin Group (FGD) dan wawancara dengan pakar. FGD dilakukan dengan mengundang dosen pembimbing, mahasiswa, dan guru. Selain FGD dilakukan pula wawancara mendalam untuk menggali lebih dalam hal-hal yang belum dikemukan dalam FGD. Data hasil FGD dianalisis secara deskriptif untuk menemukan pola pendampingan yang dilakukan oleh dosen kepada guru dan bagaimana peran mahasiswa calon guru dalam pendampingan.

\section{HASIL DAN PEMBAHASAN Hasil Angket}

Lewat angket kepada para guru di 19 sekolah (26 responden) ditemukan $42,3 \%$ responden sudah mengetahui PTK dan pernah mencoba membuat PTK. Responden diminta menuliskan judul PTK yang sudah dibuat, kemudian diperoleh judul yang dinyatakan sesuai dan tidak sesuai dengan kaidah (lihat Gambar 2). Hal yang mendorong guru untuk melakukan PTK adalah upaya guru memperbaiki pembelajaran, meningkatkan kompetensi diri, dan keperluan kenaikan pangkat guru (besaran persentasi ditunjukkan pada Gambar 3).

Kesesuaian Judul dengan Kaidah IImiah

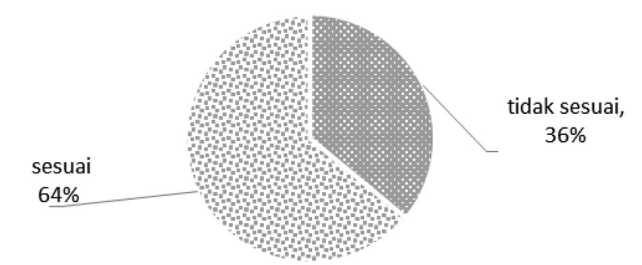

\section{Gambar 2. Persentase Kesesuaian Judul PTK dengan Kaidah IImiah}

Dorongan Guru melakukan PTK

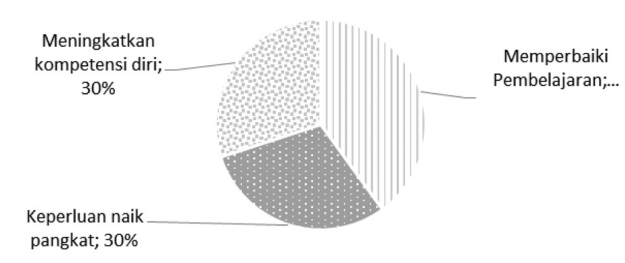

Gambar 3 Dorongan Guru melakukan PTK
Kendala saat menyusun PTK adalah terkait waktu untuk melakukan penelitian, lemahnya metodologi penelitian seperti sulit menyusun instrumen penelitian, rancangan penelitian, serta kesulitan dan ketersediaan refererensi untuk menyusun kajian pustaka. Besaran persentasi masing-masing kendala ditunjukkan pada Gambar 4 .

Kendala melakukan PTK

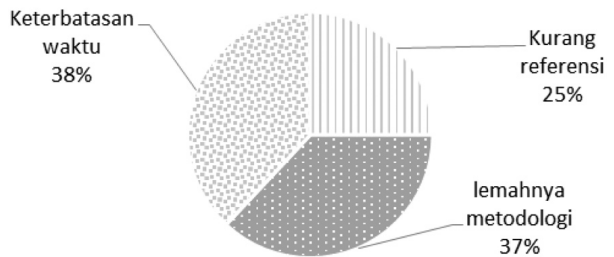

Gambar 4. Kendala Guru Melakukan PTK

Hasil angket menunjukkan guru yang melaksanakan PTK masih kurang dari 50\%, judul yang diungkapkan oleh responden guru diatas $50 \%$ sudah sesuai kaidah. Yang menarik adalah $70 \%$ alasan melakukan PTK telah mengacu pada perlunya meningkatkan kompetensi profesional, dan 30\% untuk kenaikan pangkat.

Responden yang tidak melakukan PTK memiliki alasan terkendala waktu terkait dengan beban kerja di sekolah (43\%), tidak memiliki wawasan PTK dan belum mendapatkan pelatihan/ bimbingan PTK (50\%), dan menyatakan tidak memiliki niat untuk melakukan (7\%).

\section{Rekomendasi}

Berdasarkan data kuantitatif yang diperoleh, terlihat bukn hanya pendampingan yang diperlukan, namun mereka juga memerlukan pelatihan PTK. Berdasarkan temuan tersebut, dilakukan tiga langkah sebagaimana ditunjukkan pada Gambar 5.

\section{Hasil FGD dan Wawancara}

Lewat FGD dan wawancara dengan para dosen ditemukan 14 sekolah melaksanakan PTK kolaboratif. Lewat FGD dengan dosen, mahasiswa, dan guru serta wawancara mendalam ditemukan tiga bentuk kolaborasi selama pendampingan PTK. Tiga bentuk tersebut ditunjukkan pada Tabel 1. 

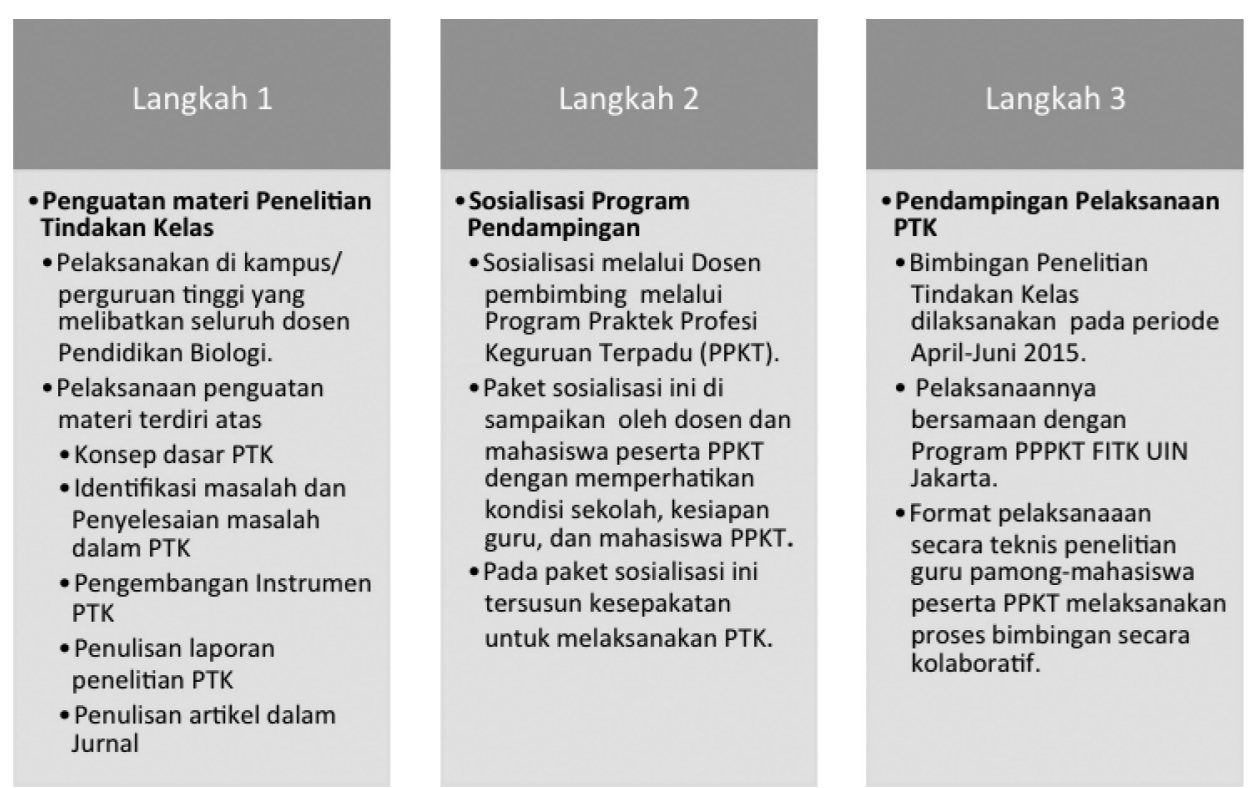

Gambar 5. Tiga Langkah Tindakan Berdasarkan Temuan Data Kuantitatif

Tabel 1. Tiga Bentuk Pendampingan PTK Kolaboratif antara PT dan Sekolah

\begin{tabular}{|c|c|c|c|c|}
\hline Model & Jumlah & \multicolumn{3}{|c|}{ Peranan } \\
\hline Pendampingan & Sekolah & & & \\
\hline $\begin{array}{l}\text { PTK } \\
\text { Kolaboratif }\end{array}$ & $\%$ & Guru & Mahasiswa & Dosen \\
\hline $\mathrm{I}$ & $2(14)$ & $\begin{array}{l}\text { Pencetus ide, meneliti } \\
\text { dan melaporkan karya } \\
\text { secara mandiri }\end{array}$ & Observer & $\begin{array}{l}\text { Membimbing penulisan } \\
\text { karya ilmiah }\end{array}$ \\
\hline II & $1(7)$ & $\begin{array}{l}\text { Pencetus ide, meneliti, } \\
\text { dan memantau } \\
\text { pelaporan karya } \\
\text { ilmiah. }\end{array}$ & $\begin{array}{l}\text { Pencetus ide, } \\
\text { mengobservasi, dan } \\
\text { menulis pelaporan } \\
\text { karya ilmiah. }\end{array}$ & $\begin{array}{l}\text { Dosen mengobservasi } \\
\text { dan membimbing } \\
\text { penulisan karya ilmiah. }\end{array}$ \\
\hline III & $8(73)$ & $\begin{array}{l}\text { Berdiskusi ide } \\
\text { penelitian, observasi, } \\
\text { memantau pelaporan } \\
\text { karya ilmiah }\end{array}$ & $\begin{array}{l}\text { Ide, meneliti, } \\
\text { menulis, melaporkan }\end{array}$ & $\begin{array}{l}\text { Membimbing penulisan } \\
\text { karya ilmiah }\end{array}$ \\
\hline & $3(27)$ & $\begin{array}{l}\text { Observasi, memantau } \\
\text { pelaporan karya } \\
\text { ilmiah }\end{array}$ & $\begin{array}{l}\text { Pencetus ide, } \\
\text { meneliti, menulis } \\
\text { pelaporan karya } \\
\text { ilmiah }\end{array}$ & $\begin{array}{l}\text { Membimbing penulisan } \\
\text { karya ilmiah }\end{array}$ \\
\hline
\end{tabular}

\section{Model Pendampingan PTK Kolaborasi I}

Model pendampingan PTK kolaborasi dengan formulasi dosen dan guru berdiskusi untuk melakukan PTK. Formulasi model kolaborasi I ditunjukkan pada Gambar 7.

Model Kolaborasi I dilaksanakan oleh guru dengan proses bimbingan tidak sekedar tatap muka di kelas, namun melalui email, atau hardfile yang langsung dikoreksi oleh dosen. Mahasiswa terlibat hanya pada saat pelaksanaan PTK sebagai observer, dan melakukan diskusi saat refleksi.

Tanggapan dosen (D1 dan D2) terhadap pelaksanaan model kolaboratif pendampingan melakukan PTK positif khususnya mendorong guru untuk melakukan PTK sekaligus memahami manfaat hasil PTK yang telah dilakukan (Tabel 2).

Keberhasilan penerapan kolaborasi ini dipengaruhi oleh kesiapan guru, komitmen, motivasi, pengetahuan awal yang baik untuk melaksanakan PTK, Kendala waktu menjadi faktor utama sehingga model kolaborasi ini belum sepenuhnya mengembangkan kemandirian guru untuk meneliti di kelas.

Pada model ini guru dominan menyusun proposal, melaksanakan, melaporkan PTK dan 


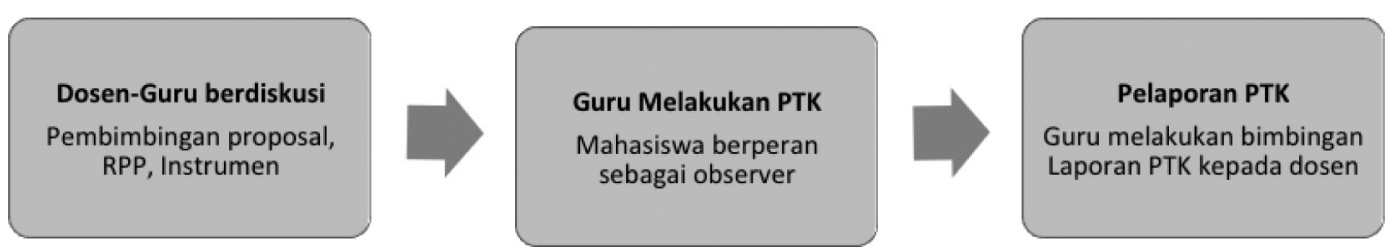

Gambar 7. Model Pendampingan PTK Kolaborasi I

Tabel 2. Tanggapan Dosen terhadap Pelaksanaan Model Pendampingan PTK

\begin{tabular}{|c|c|c|}
\hline Pertanyaan & Dosen 1 (D1) & Dosen 2 (D2) \\
\hline $\begin{array}{l}\text {-Apakah Pola } \\
\text { pendampingan PTK } \\
\text { (kolaborasi) meningkatkan } \\
\text { keterampilan meneliti? }\end{array}$ & $\begin{array}{l}\text { Belum karena keterbatasan } \\
\text { untuk pertemuan tatap muka }\end{array}$ & $\begin{array}{l}\text { Ya, dapat meningkatkan } \\
\text { keterampilan menliti guru } \\
\text { khususnya dalam memformulasikan } \\
\text { masalah, dan pelaksanaan PTK }\end{array}$ \\
\hline $\begin{array}{l}\text {-Apakah pola } \\
\text { pendampingan (kolaborasi) } \\
\text { menumbuhkan kemauan } \\
\text { guru melakukan PTK? }\end{array}$ & $\begin{array}{l}\text { Cukup mendorong dalam } \\
\text { melakukan PTK }\end{array}$ & $\begin{array}{l}\text { Ya, mendorong melaksanakan } \\
\text { PTK, termotivasi karena diperlukan } \\
\text { juga untuk persyaratan kenaikan } \\
\text { pangkat }\end{array}$ \\
\hline $\begin{array}{l}\text {-Apakah pola } \\
\text { pendampingan (kolaborasi) } \\
\text { menumbuhkan kemandirian } \\
\text { guru melakukan PTK? }\end{array}$ & $\begin{array}{l}\text { Guru belum sepenuhnya } \\
\text { mandiri karena banyak } \\
\text { terkendala waktu yang } \\
\text { dihadapi guru, untuk } \\
\text { melakukan kegiatan PTK } \\
\text { terutama dalam hal penulisan } \\
\text { laporan PTK }\end{array}$ & $\begin{array}{l}\text { Belum mandiri khususnya dalam } \\
\text { penyusunan proposal (seperti } \\
\text { memastikan solusi dari } \\
\text { permasalahan secara teoritik, } \\
\text { instrumen penelitian) dan } \\
\text { penulisan laporan PTK }\end{array}$ \\
\hline $\begin{array}{l}\text {-Hal positif yang muncul } \\
\text { dari guru setelah pola } \\
\text { pendampingan (kolaborasi) } \\
\text { dilakukan }\end{array}$ & $\begin{array}{l}\text { Mau memulai melaksanakan } \\
\text { penelitian }\end{array}$ & $\begin{array}{l}\text { Guru termotivasi untuk menulis } \\
\text { laporan sesuai kaidah, penting } \\
\text { untuk pengembangan karier guru }\end{array}$ \\
\hline
\end{tabular}
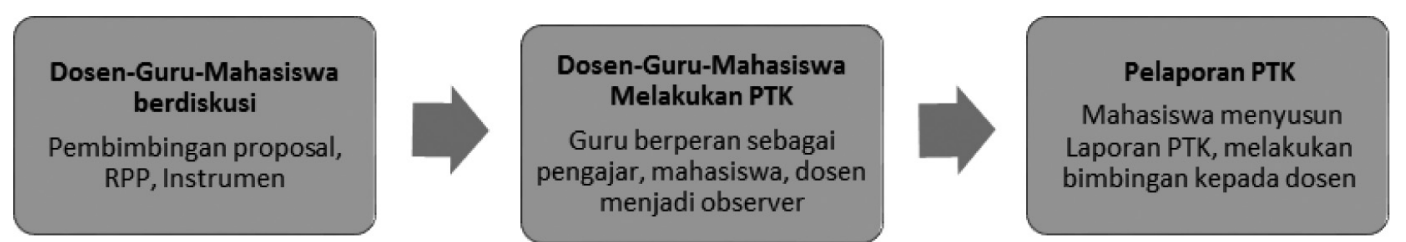

Gambar 8 Model Pendampingan Kolaborasi MK 2

melakukan bimbingan secara intensif dengan dosen. Pada pelaksanaanya diperlukan motivasi guru dan dosen yang kuat dalam proses pembimbingan, selain itu keberadaan mahasiswa saat pelaksanaan PPKT masih dianggap memberikan chemistry, khususnya mempermudah dalam menemukan referensi,

Tanggapan mahasiswa pada model kolaborasi ini positif, khususnya, mahasiswa secara langsung mendapatkan contoh tindakan guru menyelesaikan masalah kelas. Mahasiswa merasakan situasi yang nyaman, berkesempatan ikut serta mengamati jalannya penelitian.

\section{Model Pendampingan PTK Kolaborasi II}

Pada model ini guru dan mahasiswa berdiskusi memformulasikan solusi dari masalah, guru melakukan penelitian, mahasiswa sebagai observer, proses bimbingan dilakukan oleh dosen. Model pendampingan kolaboratif II ditunjukkan pada Gambar 8.

Tanggapan dosen terhadap penerapan model ini positif ditinjau dari interaksi dosenmahasiswa-guru membentuk situasi kolegial. Posisi dosen sebagai ahli yang dapat memandu guru-mahasiswa dalam memformulasikan solusi dari permasalahan yang ditemukan di kelas. Pada tingkat teknis, penyusunan RPP, instrumen secara kolaboratif dilakukan oleh guru dan mahasiswa. 
Tabel 3. Tanggapan Dosen terhadap Pelaksanaan Model Pendampingan PTK

\begin{tabular}{ll}
\hline Pertanyaan & Dosen 3 (D3) \\
\hline $\begin{array}{l}\text { Apakah Pola pendampingan PTK } \\
\text { (kolaborasi) meningkatkan keterampilan } \\
\text { meneliti? }\end{array}$ & $\begin{array}{l}\text { Ya, meningkat. Keterampilan meneliti terdiri dari } \\
\text { identifikasi masalah sampai ditemukannya solusi. } \\
\text { Penyusunan instrumen, RPP dilakukan oleh guru- } \\
\text { mahasiswa. }\end{array}$ \\
$\begin{array}{l}\text { Apakah pola pendampingan (kolaborasi) } \\
\text { menumbuhkan kemauan guru melakukan }\end{array}$ & $\begin{array}{l}\text { Ya, semakin percaya diri khususnya setelah } \\
\text { melaksanakan PTK. Ada keinginan untuk } \\
\text { melakukannya di materi yang berbeda }\end{array}$ \\
$\begin{array}{l}\text { Apakah pola pendampingan (kolaborasi) } \\
\text { menumbuhkan kemandirian guru } \\
\text { melakukan PTK? }\end{array}$ & $\begin{array}{l}\text { Belum mandiri secara menyeluruh, khususnya pada } \\
\text { pengembangan instrumen dan penyusunan laporan }\end{array}$ \\
$\begin{array}{l}\text { Hal positif yang muncul dari guru setelah } \\
\text { pola pendampingan (kolaborasi) dilakukan }\end{array}$ & $\begin{array}{l}\text { PTK } \\
\text { Belajar dan mau melakukan PTK }\end{array}$ \\
\hline
\end{tabular}

Guru merasakan manfaat dari model kolaboratif II. Tanggapan guru terhadap kolaborasi model II adalah sebagai berikut.

"Sudah tepat model ini karena saya sebagai guru biologi banyak terbantu melakukan PTK, Ibu Dosen masuk kelas memantau langsung dan memberikan masukan seharusnya dilakukan. Kemitraan ini sejalan dengan Program Sekolah saya yang termasuk Sekolah Model 132 di Indonesia Program OJL On Job Learning. Dalam pelaksanaannya memang saya yang melakukan mahasiswa yang observer, waktu pengolahan data juga saya terlibat seperti mahasiswa yang di siklus 1 seperti ini, nanti yang di siklus 2 dilengkapi. Jadi ikut terlibat walaupun mungkin yang lebih banyak Ibu dan mahasiswa, masuknya ibu dosen ke dalam kelas jadi saya sendiri langsung tau jadi harusnya begitu"

Keterangan : R (Responden)-G (Guru ken)-M (Model Pendampingan ke-n)

Tanggapan mahasiswa terhadap bentuk kolaborasi ini. Secara umum, mahasiswa tidak keberatan dengan model kolaborasi ini. Model II dianggap yang paling nyaman, sekaligus mahasiswa dapat langsung belajar dari guru pamong. Selain melihat langsung proses perbaikan pembelajaran, mahasiswa mendapat pengalaman melakukan diskusi reflektif. Model kolaborasi II cukup ideal, memberikan kesempatan kepada guru pamong dan mahasiswa untuk belajar bersama. Mahaiswa lebih terasa dibimbing dalam pengajarannya.
"Pengalaman yang memuaskan dapat berdiskusi bersama dengan guru dan dosen. Saya setuju dengan kolaborasi ini. Diskusi sudah dilakukan sejak penentuan judul PTK, saya mengamati guru saat melaksanakan PTK. Penyusunan laporan dilakukan bersama. Saya tidak merasa terbebani, saya juga mendapatkan pengalaman melakukan penelitian bersama guru”

Keterangan : $R$ (Responden)-M (Mahasiswa ke-n)-M (Model Pendampingan ke-n)

\section{Model Pendampingan PTK Kolaborasi III}

Model kolaborasi ini lebih menekankan aktivitas PTK oleh mahasiswa dengan bimbingan guru dan dosen. Pada model ini, terdapat variasi pelaksanaan pendampingan PTK, yakni dibedakan berdasarkan dominasi kolaborasinya.

Hasil FGD bersama guru dan mahasiswa terungkap bahwa model pendampingan PTK kolaborasi ini, terjadi dengan beberapa alasan, yakni (1) kurang tersosialisasi program dari pihak prodi kepada sekolah (guru pamong), maupun prodi kepada mahasiswa calon guru (2) guru pamong memiliki tugas strukural yang padat pada periode tersebut, sehingga tidak dapat melaksanakan bentuk kolaborasi yang diharapkan, (3) masalah kesehatan guru pamong di mitra sekolah tersebut. Berikut cuplikan hasil diskusi bersama guru pamong saat FGD.

-Kendala kesehatan- $[$ kolaborasi ini sangat membantu guru, mahasiswa sangat kreatif, dosen dan mahasiswa mendorong 
untuk melakukan PTK di kelas. Khusus saya terkendala kesehatan sehingga belum bisa berperan banyak, dosen memberikan wawasan PTK] R-G4-K3

- kendala tugas administratif - [saya berdiskusi dengan mahasiswa terkait penentuan judul PTK, saya melakukan koreksi RPP, LKS yang mereka susun, mahasiswa melakukan PTK, saya sekalikali menjadi observer, ada mahasiswa lain menjadi observer, dan refleksi saya berikan, laporan PTK sepenuhnya mahasiswa yang menyusun]R-G-K3

-kendala kurangnya sosialisasi-[saya diberi tahu mahasiswa bahwa mereka akan penelitian PTK, mahasiswa berkonsultasi tentang judul, selanjutnya saya mengkoreksi instrumen, RPP mereka. Saat penelitian, saya mengamati di kelas dan memberi masukan, termasuk laporan akhir saya baca juga. Secara umum, mahasiswa bisa melakukannya. Saya baru tahu saat FGD ini kalau saya bisa melakukan PTK juga, saya ingin sekali melakukannya.] $R-G 6-K 3$

(Ket: $R=$ Responden, Gn=Guru ke-n, Kn= Model Kolaborasi ke-n)
Tanggapan Ahli terhadap Model Pendampingan yang Dihasilkan

Model Pendampingan PTK Kolaboratif I ideal untuk meningkatkan keterampilan guru meneliti, namun kolaborasi minimal di pihak mahasiswa. Otomatis ini tidak sesuai dengan tujuan riset yakni menemukan bentuk pendampingan PTK kolaborasi saat pelaksanaan Program Profesi Kegurua Terpadu (PPKT)

Model Pendampingan PTK Kolaboratif II ideal karena melibatkan ketiga pihak secara proporsional, sehingga tujuan menemukan model pendampingan PTK kolaboratif terpenuhi. Penulisan laporan penelitian pada Model 2 seharusnya tidak hanya melibatkan mahasiswa tetapi juga guru karena ide penelitian berasal dari dua subjek tersebut.

Pada Model Pendampingan PTK Kolaboratif III seharusnya keterlibatan guru sebagai reviewer tidak hanya pada bagian RPP dan instrumen tetapi juga pada pencetusan ide sampai pelaporannya. Model ini sangat dominan kinerja penelitian pada mahasiswa. Model ini tidak disarankan untuk tujuan Pendampingan PTK Kolaboratif yang ingin melibatkan seluruh pihak. Utamanya mahasiswa calon guru belum diperkenankan secara mandiri melakukan PTK, mengingat esensi PTK secara absah ilmiah dilakukan oleh guru yang telah berpengalaman mengajar.

Tabel 4. Tanggapan Dosen terhadap Pelaksanaan Model Pendampingan PTK

\begin{tabular}{|c|c|c|}
\hline Pertanyaan & Dosen 4 (D4)* & Dosen 5 (D5)** \\
\hline $\begin{array}{l}\text { Apakah Pola pendampingan PTK } \\
\text { (kolaborasi) meningkatkan } \\
\text { keterampilan meneliti? }\end{array}$ & $\begin{array}{l}\text { Tidak. Lebih berfokus pada } \\
\text { mahasiswa }\end{array}$ & $\begin{array}{l}\text { Tidak. Mahasiswa lebih } \\
\text { dominan. }\end{array}$ \\
\hline $\begin{array}{l}\text { Apakah pola pendampingan } \\
\text { (kolaborasi) menumbuhkan } \\
\text { kemauan guru melakukan PTK? }\end{array}$ & $\begin{array}{l}\text { Ada keingingan, dalam diskusi saat } \\
\text { berkunjung ke sekolah, guru } \\
\text { sebenarnya memliki keinginan } \\
\text { melakukan PTK, Terkendala waktu } \\
\text { dan pengetahuan }\end{array}$ & $\begin{array}{l}\text { Ada, terkendala oleh } \\
\text { padatnya kegiatan di } \\
\text { semester ini (genap). }\end{array}$ \\
\hline $\begin{array}{l}\text { Apakah pola pendampingan } \\
\text { (kolaborasi) menumbuhkan } \\
\text { kemandirian guru melakukan } \\
\text { PTK? }\end{array}$ & $\begin{array}{l}\text { Tidak, kolaborasi lebih dominan } \\
\text { mahasiswa, namun interaksi ini } \\
\text { tetap memberikan sinergi positif } \\
\text { untuk mahasiswa belajar, namun } \\
\text { untuk guru belum terlihat }\end{array}$ & $\begin{array}{l}\text { Tidak. Dominan } \\
\text { mahasiswa, seharusnya } \\
\text { guru terlibat saat } \\
\text { pengajaran, ada } \\
\text { miskomunikasi }\end{array}$ \\
\hline $\begin{array}{l}\text { Hal positif yang muncul dari guru } \\
\text { setelah pola pendampingan } \\
\text { (kolaborasi) dilakukan }\end{array}$ & $\begin{array}{l}\text { Ada, ingin melakukan PTK di } \\
\text { semester ke depan }\end{array}$ & $\begin{array}{l}\text { Ya, lebih di sosialisasikan } \\
\text { secara optimal }\end{array}$ \\
\hline
\end{tabular}

Keterangan :

* Dosen pada Model kolaborasi 3 di 8 sekolah mitra

**Dosen pada Model Kolaborsi 3 di 3 sekolah mitra. 
Tabel 5. Validasi Ahli Model Pendampingan PTK Kolaboratif

\begin{tabular}{|c|c|c|c|c|c|c|}
\hline \multirow[b]{2}{*}{ Model } & \multicolumn{3}{|c|}{ Peranan } & \multicolumn{3}{|c|}{ Validasi Ahli } \\
\hline & Guru & Mahasiswa & Dosen & Dominasi & $\begin{array}{l}\text { Kola- } \\
\text { borasi }\end{array}$ & $\begin{array}{l}\text { Reko- } \\
\text { mendasi }\end{array}$ \\
\hline I & $\begin{array}{l}\text { Pencetus ide, } \\
\text { meneliti dan } \\
\text { melaporkan karya } \\
\text { secara mandiri }\end{array}$ & Observer & $\begin{array}{l}\text { Membimbing } \\
\text { penulisan karya } \\
\text { ilmiah }\end{array}$ & $\begin{array}{l}\text { Guru- } \\
\text { Dosen }\end{array}$ & Kurang & Tidak \\
\hline II & $\begin{array}{l}\text { Pencetus ide, } \\
\text { meneliti, dan } \\
\text { memantau } \\
\text { pelaporan karya } \\
\text { ilmiah. }\end{array}$ & $\begin{array}{l}\text { Pencetus ide, } \\
\text { mengobservasi, } \\
\text { dan menulis } \\
\text { pelaporan karya } \\
\text { ilmiah. }\end{array}$ & $\begin{array}{l}\text { Dosen } \\
\text { mengobservasi } \\
\text { dan } \\
\text { membimbing } \\
\text { penulisan karya } \\
\text { ilmiah. }\end{array}$ & $\begin{array}{l}\text { Guru- } \\
\text { Mahasiswa } \\
\text {-Dosen }\end{array}$ & Seimbang & $\mathrm{Ya}$ \\
\hline \multirow[t]{2}{*}{ III } & $\begin{array}{l}\text { Mendiskusikan } \\
\text { ide penelitian, } \\
\text { Observasi } \\
\text { penelitian dan } \\
\text { memantau } \\
\text { pelaporan karya } \\
\text { ilmiah }\end{array}$ & $\begin{array}{l}\text { Pencetus ide, } \\
\text { meneliti, } \\
\text { menulis } \\
\text { pelaporan karya } \\
\text { ilmiah }\end{array}$ & $\begin{array}{l}\text { Membimbing } \\
\text { penulisan karya } \\
\text { ilmiah }\end{array}$ & $\begin{array}{l}\text { Mahasiswa } \\
\text {-Dosen }\end{array}$ & Kurang & Tidak \\
\hline & $\begin{array}{l}\text { Observasi } \\
\text { penelitian dan } \\
\text { memantau } \\
\text { pelaporan karya } \\
\text { ilmiah }\end{array}$ & $\begin{array}{l}\text { Pencetus ide, } \\
\text { meneliti, } \\
\text { menulis } \\
\text { pelaporan karya } \\
\text { ilmiah }\end{array}$ & $\begin{array}{l}\text { Membimbing } \\
\text { penulisan karya } \\
\text { ilmiah }\end{array}$ & $\begin{array}{l}\text { Mahasiswa } \\
\text {-Dosen }\end{array}$ & Kurang & Tidak \\
\hline
\end{tabular}

Pengetahuan guru di sekolah mitra yang diteliti menunjukkan respon positif bahwa $70 \%$ alasan melakukan PTK diperlukan untuk meningkatkan kompetensi profesional guru dan 30\% terungkap untuk kenaikan pangkat yang merupakan faktor yang penting untuk dipertimbangkan. Ini mengindikasikan adanya kesadaran bahwa pentingnya melakukan penelitian PTK dikaitkan karier guru.

Kendala waktu menjadi alasan yang cukup dominan disampaikan guru sebagai alasan tidak melakukan PTK (43\%), selain alasan dominan adalah tidak memiliki wawasan dan belum mendapatkan pelatihan/bimbingan PTK (50\%). Berdasarkan angket menunjukkan mereka yang belum melakukan PTK karena terkendala seperti perlunya bimbingan/pelatihan/pendampingan dan memiliki keterbatasan waktu. Hasil ini sejalan dengan Sukidjo (2014:377), yaitu bahwa 29\% guru masih menghadapi kendala untuk melaksanakan PTK, baik kendala internal (dalam menemukan masalah, mengolah data serta tiadanya pembimbing PTK).

Hasil validasi pakar merujuk pada model ideal yang sesuai dengan fokus kajian yakni kolaborasi antara mahasiswa calon guru dan guru tanpa melanggar esensi PTK adalah Model Pen- dampingan PTK II. Model pendampingan PTK II mengakomodasi peran mahasiswa sebagai calon guru yang memerlukan contoh langsung terkait penerapan PTK di sekolah sementara guru tetap berperan sebagai guru yang layak melaksanakan PTK di kelas.

Model pendampingan PTK kolaborasi II direpson positif pada pelaksanaannya oleh dosen, guru, mahasiswa. Model kolaborasi II ini menempatkan interaksi kolegial baik dari awal perencaanaan, tindakan, pengamatan, dan refleksi. Calon guru/mahasiswa seharusnya mempelajari bagaimana mengembangkan pembelajaran dan materi sesuai harapan guru di sekolah secara kooperatif (Weisner, et.al, 2004:1 ).

Mahasiswa diposisikan sebagai pembelajar, magang, berlatih menjadi observer, membantu guru dalam mempersiapkan pelaksanaan PTK dengan cara bertukar informasi, menganalisis instrumen, maupun RPP. Mahasiswa calon guru perlu mendapatkan contoh langsung terkait pelaksanaan PTK di sekolah. Potensi mahasiswa dengan keluangan waktunya dapat mengembangkan bahan ajar, media pembelajaran, dan asesmennya. Guru, dengan intensitas waktu yang terbatas, dan tidak bisa meninggalkan tanggungjawabnya di kelas dapat memberikan contoh praktek langsung 
menyelesaikan permasalahan di kelas berdasarkan pengalamannya.

Pada proses akhir, guru dan mahasiswa melaporkan hasil akhir dalam bentuk laporan PTK sesuai dengan kaidah ilmiah dengan bimbingan dosen. Pada akhirnya bentuk kolaborasi ini memberikan peluang komunikasi yang luwes antara guru-mahasiswa yang sedang menjalankan praktek pengajaran langsung. Aldridge (2012:260) menyatakan proses kooperatif melatih mahasiswa untuk memahami bagaimana guru mengambil keputusan pedagogi, mengkonstruk pengetahuan baru, mentransformasi praktek pengajaran Penelitian tindakan self reflektif, memperbaiki praktek pengajarannya.

Model penampingan PTK kolaborasi 2 sejalan dengan hasil penelitian Keating (1998:382) melaporkan pelaksanaan penelitian tindakan ( $A c$ tion Research) di California State University San Marcos (CSUSM), program ini mengintegrasikan penelitian tindakan dalam perkuliahan dan pengalaman lapangan (PPL). Pihak Perguruan Tinggi bekerjasama dengan sejumlah sekolah untuk menggabungkan program Perguruan Tinggi dalam rangka "penyiapan guru abad 21". Keterampilan riset dalam hal ini Penelitian Tindakan Kelas menjadi hal penting dibekalkan kepada calon guru untuk menghadapi abad 21.

Pihak sekolah dalam hal ini guru di sekolah dianggap sebagai agen penting untuk melakukan refleksi sekaligus menjadi seorang pemikir kritis yang secara kontinu. Keterlibatannya secara proaktif memiliki peran yang besar bagi calon guru. Prodi/Fakultas memiliki peran signifikan dalam hal interaksi yang menguntungkan antara mahasiswa dan guru pamong di sekolah. Lee (2013:51) menyatakan efektifitas penelitian tindakan bergantung kesepakatan dan komitmen yang dilakukan secara kolaboratif.

Borg, et al (2015:2 ) menyatakan calon guru yang melaksanakan PTK pada dasarnya melakukan inkuiri saat proses refleksi di kelas, diharapkan pengalamannya dapat memberikan dampak positif pada mahasiswa setelah menyelesaikan pendidikannya.

\section{SIMPULAN}

Penelitian menghasilkan tiga model pendampingan PTK kolaborasi, yaitu model I (guru bersifat dominan), model II (peran guru bersifat moderat), dan model III (guru bersifat resesif). Model I guru sebagai pencetus ide dan melakukan penelitian mandiri, mahasiswa berperan sebagai observer, proses bimbingan dilakukan oleh dosen pembimbing. Model II guru dan mahasiswa mencetuskan ide riset, guru melaksanakan PTK, proses bimbingan dilakukan oleh dosen pembimbing. Model III guru bersama mahasiswa atau mahasiswa secara mandiri mencetuskan ide riset, mahasiswa melaksanakan PTK, proses bimbingan dilakukan dosen.

Model ideal yang mengakomodasi peran guru, mahasiswa, dosen adalah model II. Model pendampingan PTK kolaborasi ini menempatkan mahasiswa sebagai pembelajar, magang, yang berinteraksi langsung dengan permasalahan sekolah dan memperoleh pengalaman langsung tindakan pedagogi yang dilakukan guru. Proses ini secara esensial tidak menyalahi hakikat PTK, bahwa guru berpengalamanlah yang memiliki kewenangan melakukan riset PTK.

\section{UCAPAN TERIMAKASIH}

Kami mengucapkan terimakasih kepada berbagai pihak atas bantuannya dalam penelitian ini. Terima kasih kepada Prof. Dr. Ana Permanasari, M.Si yang telah memvalidasi model pendampingan PTK kolaborasi. Terima kasih kepada Pusat Penelitian UIN Syarif Hidayatullah Jakarta yang telah memberikan hibah penelitian publiksi nasional tahun anggaran 2015/2016.

\section{DAFTAR PUSTAKA}

Agung, S., Bulte, A. M. W., \& Pilot, A. 2012. Professional Development Activities: A Case Study Towards Sustaining a Community of Teachers During Decentralization of Education. Unpublished manuscript.

Akkerman, S. F., \& Bakker, A. 2011. "Boundary Crossing and Boundary Objects." Review of Educational Research, 81(2),pp. 132169.

Aldridge, Jill M., Barry J. F., Lisa, B., Jeffrey D.2012. "Using a New Learning Environment Questionnaire for Reflection in Teacher Action Research". International Journal Science Teacher Education (23) pp 259-290.

Widodo, A., Riandi, dan Bambang, S. 2011. Paket Program Coaching Berbasis Video untuk Peningkatan Kompetensi Mengajar Guru 
Sains Cakrawala Pendidikan, Februari 2011, Th. XXX, No. 1.

Borg, S., Sanchez S, Hugo. 2015. Key Issues in Doing and Supporting Language Teacher Research. International Perspectives on English Language Teaching. pp 1-13.

Fakultas Ilmu Tarbiyah dan Keguruan UIN Jakarta. 2015 Panduan Program Profesi Keguruan Terpadu. Jakarta.

Indonesia. 2005. Undang-Undang Republik Indonesia Nomor 14 Tahun 2005 Tentang Guru dan Dosen. Jakarta: Rajagrafindo.

Hendayana, S., dkk. 2006. Lesson Study Suatu Strategy untuk Meningkatkan Keprofesional Pendidik (Pengalaman IMSTEP-JICA). Bandung : UPI Press.

Keating, Joseph; Diaz-Greenberg, Rosario; Baldwin, Mark; Thousand, Jacqueline. 2016. A Collaborative Action Research Model for Teacher Preparation Programs. Journal of Teacher Education v49, n5 (Nov-Dec, 1998):381-396. Tersedia http://jte.sagepub. $\mathrm{com} /[15 / 2 / 2016]$.

Lee, G. 2013. "Using Collabrative Action Research for a Genuine School Based Educational Change : An Example Case and Referense Notes for Novice Teacher." New Horizons in Education, Vol.61, No. pp 49-69.

Mendiknas dan BKN .2010. Peraturan bersama BKN dan Kementerian Pendidikan Petunjuk Pelaksanaan Jabfung Guru dan Agka kreditnya. No 14 tahun 2010.
NRC 1996. National Education Standards. Tersedia: http://www.nap.edu/ [15/2/2016].

Nurjhani K, Mimin., Widi, P .2010 Upaya Peningkatan Kemampuan Guru dalam Pembelajaran IPA (Biologi) melalui Lesson Study. Tersedia di http://file.upi.edu diakses tanggal 15/2/2016.

Prodi Pendidikan Biologi, FITK UIN Jakarta. 2015. Laporan Pelaksanaan PPKT Prodi Pendidikan Biologi. Jakarta : Tidak dipublikasikan.

Rosiani, D., S. Martono, Kardoyo. 2014. “Pengembangan Model Pelatihan Penngkatan Kompetensi Guru mengembangkan Pembelajaran berbasis Penelitian Tindakan Kelas." Jurnal Penelitian Tindakan Sekolah dan Kepengawasan. Vol. 1, No. 2.

Sukidjo. 2014. Kompetensi PTK Guru SMP di DIY. Cakrawala Pendidikan. 2014, TH. XXXIII, (3) 368-378.

Sugiyono. 2012. Metode Metode Penelitian Kuantitatif dan Kualitatif (Mixed Methods). Bandung : Alfabeta.

Tytler, R., David, S., John C C. 2016. "Community-School Collaborations in Science: Towards Improved Outcomes Through Better Understanding of Boundary Issues." International Journal Science Teacher Education (2016) 1-19 tersedia : http://link. springer.com [15/2/2016].

Weisner, J., Salked, E.2004. Taking Technology into School A Dialogue Between a Pre service Teacher and University Supervisor. Teach Trends Vol 48 (3) pp12-17. 